\title{
Evaluating The Relevance of CRITICAl SChOOLS OF LAW AND ECONOMICS FOR THE EQUALITY RIGHTS OF WORKERS WITH DISABILITIES IN CANADA AND THE UNITED STATES
}

\author{
Ravi A. Mal.hotra ${ }^{\circ}$
}

This arficle examines the contributions of modern schools of law and economics to the equality rights of workers with disabilities. While neo-classical law' and economics generally adwocates the stupremacy of frec markets to operate without government interference and legal regulation, many of the newer schools of law and economics offer highy creative solutions and dynamic approaches that may offer real hope ro people with disabilities. The merits and weaknesses of the theories of hese modern schools are discussed in light of the social model of disability. The schools are cxamined by drawing on cxamples from Comodion and American jurisprudence. Specifically. the sixem to which the schools provide robust explanations for labour market policy is explored. The author argues that neo-institutional law and economics, feminist law and economics. and critical race theory lan and economics hold out the most promise for understanding the implications of the social model of disabiliț:
Dans cel ardick. I anfeur examine les contributions des icoles de droit et de commerce modemes atox droils d'egalité des tratuillenrs souffrant d'imalidité. Alors que te droit a l'economic neo-classigues difendem habituellement la stuprématie du marche tibre pour fonctionner sans ingérence du gowvernement ni reglenentation juridique, un grand nombre d'scoles de droit et de commerce phus récentes proposend des solwions thès créatives et des approches dinamiques poumm offrir an verisable expoir anx persommes somfram d"invalidice. Les merites et les lacumes des thiories de ces cooles modernes fom lobjer diume discussion à la lumière du modèle social d'imalidite. lex ecoles som examines au moven d'acmples fireses de la jurisprudence canadienne et amcricaine. Tout particulièrement, on étudie lamesure dans laquelle ces écoles foumissent de solides explications pour we politique de marché du tratuil. $L$ anterr fail valoir que le droit et léconomie nioinstifutionnelle. le droit ef leconomie feministe ainsi que ke atroit at liconomic essentielle en matiere raciale semblent plus promenteurs pour comprendre les implications du modele social d'invaliditi.

\section{TABLE OF CONTENTS}

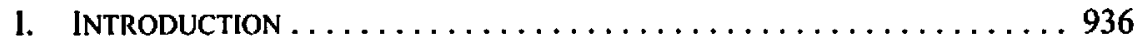

II. SCIIOOLS OF LAW AND ECONOMICS ................... 937

A. Beilavioural Law and Economics .............. 937

B. The Law and Social. Norms Tradition $\ldots \ldots \ldots \ldots \ldots . \ldots 91$

C. INSTITUTIONALISM ......................... 945

D. Neo-INSTITUTIONALISM ...................... 947

E. Feminist Theory and LAW and ECONOMICS .......... 950

F. CRITICAL Race Thfory and LaW and ECONOMICS ........ 953

III. CONCLUSION ............................... 960

Assistant Professor, Faculty of Law, Common Law Section, University of Ottawa; SJD, University of Toronto, 2007; LL.M., Harvard Law School, 20022. I thank Professor Kerry Rittich for her kind years of supervision while the doctoral dissertation from which this piece is extracted was completed. I acknowledge the funding of a SSHRC doctoral liellowship that partly funded this research. All crrors are my own responsibility. 


\section{INTRODUCTION}

In recent years, the law and economics movement has grown dramatically as one of the most influential schools of jurisprudential thought. The movement has been applied to analyze a growing number of complex legal problems in diverse areas ranging from torts to criminal law to constitutional law and far beyond.' Standing for the proposition that understanding the economic effect of legal rules and regulations is an important objective that may assist in guiding public policy, ${ }^{2}$ it has also expanded significantly to encompass a wide variety of paradigms that go beyond conventional neo-classical law and economics. The core ideas of neo-classical law and economics include the notion that rational individuals seek to maximize their preferences, that legal regulation imposes costs, and therefore, common law rules are efficient where they generate the results that the parties would have reached through a process of free exchange. ${ }^{3}$ Accepting the fact that conventional neoclassical law and economics has been subjected to numerous critiques that question the very underpinnings of its central assumptions, ${ }^{4}$ these new schools of law and economics attempt to create more subtle frameworks that can better explain social phenomena and create more robust results.

In this article, I seek to explore what these newer schools of law and economics can teach us about one of the most pressing legal and social issues of our time: the equality rights of workers with disabilities. By all accounts, people with disabilities remain impoverished and unemployed across Western societies. The widespread barriers posed by inaccessible architecture and materials unavailable to those who are blind or visually impaired speak volumes about the inclusion of disabled people in Canada and the United States as full citizens. ${ }^{5}$ While neo-classical law and economics has traditionally been associated with a tendency to advocate the supremacy of free markets to operate without government interference and legal regulation -- which this school believes will lead to negative

1 For overviews. sec c.g. Richard A. Posner. Frontiers of Legal Theory (Cambridge. Mass.: Harvard University Press. 2001) (Posner, Fromtiers); Michael J. Trebilcock. "An Introduction to Law and Economics" (1997) 23 Monash U.L. Rev. 123. Early important contributions include Guido Calabresi. "Some Thoughts on Risk Distribution and the Law of Torts" (1961) 70 Yale L.J. 499; Ronald Coase. "The Problem of Social Cost" (1960) 3 J.l. \& Econ. I.

: Strictly speaking, one may distinguish between normative law and economics that recommends policy changes to improve the legal system and positive law and economics that simply secks to explain the functioning of legal rules through economies. See David A. Hoffman \& Michael P. O'Sliea, "Can Law and Economics Be Both Practical and Principled?" (2002) 53 Ala. L. Rev. 335 at 337, n. 2.

3 Eric M. Fink, "Post-Realism, or the Jurisprudential Logic of Late Capitalism: $\Lambda$ Socio-Legal Analysis of the Rise and Diffusion of Law and Economics" (2004) 55 Hastings L.J. 931 at 934.

For a sampling of criticues. sec Duncan Kennedy, "Cost-Benefit Analysis of Entitlement Problems: A Critique" (1981) 33 Stan. L. Rev. 387 [Kennedy, "Cost-Benefil"]: Morton J. Horwitz, "Law and Economics: Science or Politics?" (1980) 8 Hofstra L. Rev. 905; Mark Kelman, "A Critique of Conservative Legal Though"" in David Kairys, ed., The Politics of lan": $A$ P'rogressive Critique, rev. ed. (New York: Panthcon Books, 1990) 436 at 441-49; Arthur Allen Letl, "Economic Analysis of Law: Some Realism about Nominalism," Commentary, (1974) 60 Va. L. Rev. 451. Space constraints preclude a full critique of neo-classical law and economics.

For a good discussion, see Richard Devlin \& Dianne Pothier, "Introduction: Toward a Critical Theory of Dis-Citizenship" in Dianne Pothier \& Richard Devlin, eds., Critical Disabilin. Theory: Essays in Philosophy. Politics, Policy, and lasw (Vancouver: University of British Columbia Press, 2006) I at I22. 
consequences that outweigh any benefits ${ }^{6}$ - many of the newer schools of law and economics offer highly creative new solutions and dynamic approaches that may offer real hope to the large number of people with disabilities living on the margins of society. In this article, I explore the merits and weaknesses of a number of these schools in light of the social model of disablement. This paradigm suggests that structural barriers are the primary cause of the problems faced by people with disabilities. ${ }^{7}$ Part II explores various critical schools of law and economics, using examples from both Canadian and American jurisprudence. I specifically explore the extent to which the various schools provide robust explanations in understanding what I believe are two important implications of the social model of disablement for labour market policy: (1) empowering workers with disabilities to have greater control over the workplace process on a day to day basis, and (2) the seamless provision of a wide range of supports and accommodations across the lifespan to allow the disabled person to effortlessly make the transition from school to work. I argue that neoinstitutional law and economics, feminist law and economics, and critical race theory law and economics hold out the most promise for understanding the implications of the social model that I have highlighted.

\section{SCHOOLS OF LAW AND ECONOMICS}

\section{A. Behavioural Laiv and Economics}

Behavioural law and economics is based on the notion that in real world conduct, rational actors systematically diverge from the expectations that one would typically derive from the principles of neo-classical economics. ${ }^{p}$ Influenced by the ideas of psychologists Daniel Kahneman and Amos Tversky, this school has sought to create a more psychologically sophisticated model of human behaviour. ${ }^{10} 1$ argue that it contains important insights that

See e.g. Fink, supra note 3 at 934-35.

For an overview, see Michacl Oliver, The Politics of Disablememt (London: Macmillan, 1990). Supra note 2 at 360.

Christine Jolls, Cass R. Sunstein \& Richard Thaler, "A Bchavioral Approach to Law and Economics" (1998) 50 Stan. L. Rev. 1471 at $1477-79$ [Jolls, Sunstein \& Thaler, "A Behavioral Approach"].

See e.g. Michael Ashley Stein, "Under the Empirical Radar: An Initial Fxpressive Law Analysis of the ADA," Book Review of Rights of Inclusion: Law and hentily in the Life Shories of Americans with Disabilitic:. by David M. Fingel \& Frank W. Munger. (2004) 90 Va. L. Kev. 115 ] it I170-74 [S1ein. "Under the Empirical Radar"]: Robern A. Prentice, "Chicago Man, K-T Man, and the Future of Behavioral Law and Economics" (2003) 56 Vand. L. Rev. 1663; Jolls, Sunsicin \& Thaler, "A Behavioral Approach, ibid. at 147-79; Russell B. Korobkin \& Thomas S. Ulen, "Law and Behavioral Science: Removing the Rationality Assumption from Law and Economics" (2000) 88 Cal. L. Rev. 1051; Jon Hanson \& David Yosifon, "The Situation: An Introduction to the Siluational Character, Critical Realism, Power Economics, and Deep Capturc"(2003) 152 U. Pa. L. Rev. 129; Clairc A. Hill. "Bcyond Mistakes: The Next Wave of Behavioural Law and Economics" (2004) 29 Queen's L.J. 563. But see Posner, Fromiers, supra note I at 252-87 (rebutting arguments of behavioural law and cconomics school as better explained by neo-classical law and economics and evolutionary biology): Richard $A$. Posner. "Rational Choice, Bchavioral liconomics, and the Law" (1998) S0 Stan. L. Rev. I551 (also rebuts arguments of behavioural law and economics school); Mark Kelman. "Bchavional Economics as Part of a Rhetorical Duet: A Response to Jolls, Sunstein, and Thaler" (1998) 50 Stan. L. Rev. 1577 |Kelman. "Behavioral Economics") (suggesting behavioural law and economics school is best seen as an interpretive trope rather than a comprehensive theory); Samuel Issacharoff; "Can There Be a Bethavioral Law and Economics?" (1998) 51 Vand. L. Rev. 1729 (questioning whether behavioural law and economies has made sufficient contributions to constitute a distinctive school). For a response by Jolls, Sunstein and Thaler to the critiques of Posner and Kelman, see Christine Jolls. Cass R. Sunstein \& 
allow one to better understand the issues faced by workers with disabilities. I conclude that the fundamental attribution error is the main contribution of behavioural law and economics for scholars trying to grasp the problems faced by workers with disabilities. I begin, however, with a discussion of bounded rationality.

It is not uncommon to accept that actors in economic models have what Herbert Simon termed "bounded rationality," or a finite intellectual capacity that systematically results in mistakes." Faced with overwhelming volumes of information, rational actors seek to take short cuts or heuristics in order to make a decision that may maximize their global utility but will not, in fact, maximize their utility for that particular decision because of the use of the heuristic. For instance, experimental studies show that when potential home owners are offered homes and provided with information on more than ten attributes for each home, the potential customers fail to maximize their utility as defined by their own stated preferences of the features they would most desire in a home. ${ }^{12}$

An important cognitive issue related to bounded rationality is what some have called, the availability heuristic. This refers to the notion that actors may overestimate the relevance of memorable characteristics in calculating informal statistical probabilities. For instance, unless prohibited from doing so by statute, jurors may wrongly assume that a defendant with a past conviction for a property offence is statistically more likely to subsequently commit murder. ${ }^{13}$ An illustration in the context of workers with disabilities would be the tendency of employers to incorrectly regard a nondisabling physical characteristic, such as obesily, as negatively affecting work performance. In the case of workers with disabilities, employers may erroneously ascribe far greater disabilities than actually exist, a linding welldocumented in sociological and psychological literature. ${ }^{14}$

The influence of context in altering behaviour in ways that would not be predicted by conventional neo-classical analysis is another issue highlighted by behavioural law and economics scholars. Framing biases provide an illustration of how the context in which information is presented dramatically affects the decisions that rational actors make when choosing under uncertain conditions. When options that generate identical values are framed as losses rather than gains with respect to a reference point, rational actors have been found

Richard Thaler, "Theories and Tropes: A Reply to Posner and Kelman" (1998) 50 Stan. L. Rev. 1593. This is only a sampling of the extensive literalure on the topic.

Nicholas Mercuro \& Steven G. Medema, Economics and the Law: From Posner in Post-Modernism (Princeton: Princeton University Press, 1997) at 130; Jolls, Sunstein \& Thaler, "A Behavioral Approach," $i b i d$. Sec also Robert C. Ellickson, "Bringing Culture and Human Frailty to Rational Actors: A Critique of Classical Law and Leonomics"(1989) 65 Chicago-Kent L. Rev, 23 at 40-43. Korobkin \& Ulen, supro nolc 10 at 1078 . Of course, an actor may maximize his or her overall utility by selecting a suboptimal oulcome lor a particular decision as a result of the use of the heuristic.

Ibid. at I087-88. Set also Cuss R. Sunstein. "Cognition and Cost-Benefit Analysis" in Matthew D. Adler \& Eric A. Posner, eds. Cost-Benefit Analywis: I.egal, Economic, and Philosophical Perspectives (Chicago: University of Chicago Press, 2001) 223 at 229-30 (discussing implications of availability heuristic in risk assessments).

14 Michelle A. Travis, "Perecived Disabilities, Social Cognition, and "Innocent Mistakes"”(2002) 55 Vand. L. Rev. 481 at 532-35 [Travis, "Perceived Disabilities"] (discussing availability heuristic in the case of workers with disabilities). 
to be more likely to select riskier options. ${ }^{15}$ This has spawned research suggesting that litigation that one would otherwise expect to settle may be prolonged precisely because of framing biases that lead defendants, rather than plaintiffs, to tenaciously litigate to avoid what they perceive as potential losses. ${ }^{16}$ As much disability discrimination in employment is related to the mistaken perception that people with disabilities may pose a threat to coworkers or to workplace equipment, ${ }^{17}$ framing biases may increase the risk that people with disabilities experience irrational discrimination. The scope of this problem is, in fact, significant and covers a wide range of disabilities including people with diabetes who use insulin and may be falsely regarded as safety risks, and people with mental health disabilities who are incorrectly regarded as a potential physical threat 10 co-workers. ${ }^{18}$

Perhaps one of the most salient behavioural effects for specifically understanding the employment barriers faced by people with disabilities is that predictions made by social psychologists tend to incorrectly attribute people's disposition to their behaviour rather than their situation. The fundamental attribution error was most infamously demonstrated in experiments conducted by Stanley Milgram at Yale University in the early 1960 s. ${ }^{19}$ Subjects were told to administer escalating voltages of electricity, as part of a role-playing exercise in which they were assigned the role of a teacher. The teachers were to punish students who stated incorrect answers to questions, even when it was clearly demonstrated that the electric shocks were harming the students. Whereas psychologists surveyed in advance incorrectly predicted that only one in 1,000 subjects would behave so unethically and cruelly as to administer the maximum voltage, nearly two out of three subjects who were assigned the role of teachers obeyed the instructions and administered the maximum voltage. ${ }^{20}$ Yet, when the experiment was moved off Yale's campus and participants were told that the experiment was run by a nondescript research company, compliance with administering the maximum shock dropped precipitously. ${ }^{21}$

Such powerful evidence of situational circumstances affecting behaviour suggests that changes to the material realities affecting people with disabilities, through the elimination of systemic barriers, could have a significant impact on improving employment outcomes in the long term. However, it also indicates that employers may be wrongly interpreting an

Korobkin \& Ulen, supra nule I0 at $1104-105$. Sec also Jeffrey J. Raclalinski. "Giains, Losses, and the Psychology of Litigation" (1996) 70 S. Cal. L. Rev. 113 (analyzing the fratning bias in the context of litigation); Tanina Rostain, "Fducating Homo Economicus: Caulionary Notes on the New Behavioral Law and Economics Movement" (2000) 34 Law \& Soc'y Rev. 973 at $978-79$ (noting differences in medical decision-making depending on whether identical choices were expressed in terms of mortality rates or survival rates).

Korobkin \& Ulen, ibid. at 1106.

19 Samuel R. Bagenstos. "The Americans with Disabilities Act as Risk Reculation" (2001) 101 Colum. L. Rev. 1479 at $1479-80$.

lbid.

14. Hanson \& Yosifon, supra note 10 al 152.

Ibid. at 152.53. See also Travis, "Pereeived Disabilities," supro note 14 (describing how behavioural psychology can help to understand discrimination against people with perceived disabilities); Michelle A. Travis, "Recapturing the Transformative Polential of Employment Discrimination Law" (2005) 62 Wash. \& Lee L. Rev. 3 (discussing how the fundamental attribution error leads to a greater focus on disposition rather than situation). For a comprehensive discussion in the context of race, see generally Jerry Kang, "Trojan Horses ol' Race" (2005) 118 Harv. L. Rev. 1480. 
employee's work conduct as limited by a perceived or actual disability when in fact that is not the case. Accordingly, employers may be wrongly terminating workers on the grounds that they are unable to do the job when this assessment is utterly inaccurate."2 Suggestions have consequently been made that the jurisprudence of Title VII, ${ }^{23}$ the foundational civil rights statute in the U.S. that prohibits racial discrimination, be reworked; the jurisprudence should move away from the disparate impact theory that requires plaintiffs to demonstrate intent to discriminate. on the part of the employer, by proving that any reasons for the employer's action be shown as pretext. Instead, it has been proposed that the disparate impact need not require a court to find that an employer had discriminatory intent, given the complexity of cognitive biases that can contribute to racial discrimination. ${ }^{24}$ This would of course adopt the Canadian framework where demonstrating an intent to discriminate is entirely irrelevant in human rights jurisprudence. ${ }^{25}$

This is not to imply that the merits of the behavioural law and economics school have not been seriously questioned. An obvious problem is that many of the behavioural quirks found to exist in controlled laboratory studies may not necessarily be replicated in the more complex real world environment where it is difficult to control for extraneous variables. More significantly, many behavioural effects have contradictory results that make it exceedingly difficult to discern what behaviour genuinely accounts for a particular decision. ${ }^{26}$ A much deeper problem lies in the concern that, to the extent that behavioural law and economics tries to translate extremely complex psychological phenomena into the cold language of the neo-classical and utility maximizing rational actor, it may unreasonably privilege self-interest as a methodological interpretation of the world and even encourage policy agendas that unwittingly reinforce self-interest as the main psychological motivation for actors. ${ }^{27}$ Studies suggest that research subjects, with training in economics, are less likely to contribute towards the cost of public goods. This raises worries that a neo-classical bias may suppress potential opportunities for co-operation and solidarity. ${ }^{2 k}$ Similarly, the lack of an overall ethical theory to guide behavioural law and economics research raises the troubling spectre of the elimination of deliberative discussions about the normative goals that guide intelligent policy formulation. ${ }^{29}$

Legal scholars continue to disagree on whether behavioural law and economics is too critical of neo-classical economics without countering with a comprehensive theory to

Travis, "Perceived Disabilities," stupres note 14 at $539-40$ (discusses a case where an employer greatly misinterpreted the impact of a nondisabling wrist injury on a worker's ability to perform her job as a registered nurse). See also Linda Hamilton Krieger, "The Content of Our Categories: A Cognitive Bias Approach to Discrimination and Equal Eimployment Opportunity" (1995) 47 Stan. L. Rev. I 161 at I 199212 [Krieger, "Conlent"] (suggesting social cognition theory has undermined disparate treatment test under Tille VII that requires plainilifs to demonstrate intent). Civil Rights Act, 42 U.S.C. Tille VII \$2000) (1964).

Krieger, "Content," supra note 22 at 1242. Sce also Rebecea Hanner White \& Linda Hamilton Krieger, "Whose Motive Matters? Jiscrimination in Multi-Actor Employment Decision Making" (2001)61 Lal. L. Rev. 495.

" Dianne Pothicr. "Appendix: Legal Developments in the Supreme Court of Canada Regarding Disability" in Pothier \& Devlin, supra note S, 305 at 307-308. 
replace it, or whether it is insufficiently critical of neo-classical law and economics. ${ }^{30}$ From the perspective of the implications for analyzing changing labour markets that I derived from the social model of disablement, behavioural law and economics has profound limitations. While it makes a valuable critique of neo-classical law and economics in identifying shortcomings of the rational actor model and in highlighting the role of the fundamental attribution error, the solutions that it proffers, even if one were able to determine whether a particular effect were in play at a certain point, are far 100 individualistic to grapple with the structural discrimination faced by workers with disabilities. The complex issues of discrimination affecting workers with disabilities cannot be easily resolved by a turn to behavioural law and cconomics. Even the most practical recommendations by the behavioural law and economics school, such as reformulating the Title VII jurisprudence to move away from a requirement of proving intent, are not only moot in a disability context predicated on the provision of accommodation without requiring a showing of intent, but contingent on a model of piecemeal change by the adjudication of individual complaints. A far more structural approach is needed that empowers workers in the daily production process. I regard behavioural law and economics as, at best, a partial solution to the many problems posed by neo-classical law and economics and suggest that it has not gone far enough in critiquing the assumptions of neo-classical economics, notwithstanding its merit in understanding certain aspects of disability discrimination.

\section{B. The LAW ANd SOCIAL NORMS Tradition}

Another important branch of law and economics is the law and social norms tradition. The tradition refers to a relatively new ${ }^{31}$ but rapidly growing body of literature by scholars engaged in this sub-branch of law and economics to explain the complex relationship between individuals rational choices and social norms. ${ }^{32}$ A social norm may be defined as

See Posner. Fronticrs, supra note $I$ at 252-87 (arguing that behavioural law and economics does not constilute a theory adequate to replace neo-elassieal law and economics); Kelman, "Behavioral Economics," supra note 10 (arguing that behavioural law and cconomics is insufficiently critical of ncoclassical law and cconomics).

Of course, scholars who do not necessarily identify as law and econonics scholars have been noting the use of social norms rather than law to setile disputes among business people for a very long time. See the classic findings in Stews art Macaulay. "Non-Contractual Relations in Business: A Preliminary Study" (1963) 28 American Sociology Review 55 (linding businesses settle disputes informally).

See e.g. Fric A. Posner, Law and Social Norms (Cambridge, Mass.: Harvard University Press, 2000) [Posner, law]: Richard H. McAdams, "Signaling Discount Rates: Law, Norms, and Fconomic Methodology," Book Review of Law and Social Norms by Liric A. Posner, (2001) 110 Yale L.J. 625 at 626 [McAdams, "Signaling"]; Posner, Fromiers, supra note 1 at 288-315; Rober D. Cocter, "Decentralized Law for a Complex Economy: The Structural Approach to Adjudicating the New Law Merchant" (1996) I44 U. Pa. L. Rev. 1643. For lucid critiques of the law and social norms tradition as ultimately limited by many of the same weaknesses of the broader neo-elassical law and economics school, sec Lawrence E. Mitchell, "Understanding Norms" (1999) 49 U.T.L.J. 177 [Mitchell. "Understanding"| (noting "In]orms can be identified as eflicient or ineflicient only if" we know the ends they are to serve" (at 189)); Mark Tushnet. "'Fverything Old is New Again": Early Reflections on the "New Chicago School"" [1998] Wis. L. Rev. 579 (observing that the law and social nom tradition "would profit intellectually by tuming its attention to the law and society tradition associated with Marx. Durkheim, and Weber" (at 580)). See also Lauren B. Fdelman. "Rivers of Law and Contesled Terrain: A Law and Socicly Approach to Economic Rationality" (2004) 38 Law \& Soc'y Rev. 181 (noting that the law and society school "provides a means of understanding how both law and the economy are embedded within a social environment in which power malters and in which highly institutionalized beliefs, structures, and rituals jointly shape the nature of legality and rationality" (at 193 [cmphasis in 
"a rule that is neither promulgated by an official source, such as a court or a legislature, nor enforced by threat of legal sanctions, yet is regularly complied with." 33 Intermalization of a sense of duty or worries regarding the imposition of non-legal sanctions, or both, creates social norms. ${ }^{34}$ Signaling of social norms is an action that allows those who have excellent reputations as co-operative individuals and who have sufficiently low discount rates in conducting transactions because they value long-term relationships, known as the "good type" in law and social norms theory, to make this known and distinguish themselves from "bad types" by expending scarce resources on the signal. ${ }^{35}$ Norm entrepreneurs, such as marketing consultants, academics, and politicians, engage in signals, frequently modelled using game theory frameworks such as the famous Prisoner's Dilemma, ${ }^{36}$ in order to alter the public's perception of what norms constitute signals of low discount rates. ${ }^{37}$

The law and social norms tradition has been used to explain racial discrimination in the U.S. as far more than mere preferences. Rather, it is a matter of members of the prominent racial group rationally signalling their commitment, through costly acts of discrimination against minorities, to other "good type" members in the prominent group in order to maintain their reputation as a reliable and loyal partner with whom to conduct trade. ${ }^{3 *}$ However, it has been rightly observed that the signalling model has significant limitations in convincingly explaining race discrimination; racist ideology is based on the notion that marginalized racial minorities, such as African-Americans, make poor trading partners because they are inferior on a wide range of characteristics including trustworthiness, intelligence, and work ethic. Therefore, signalling would hardly impose a true cost since it would be a direct maximization of the discriminating party's utility to engage in bigoted and racist acts. ${ }^{39}$ Despite such

(original])). As with (he behavioural law and economics scheol, this is only a fraction of the massive literature.

3. Posncr, Fromicrs, supra note 1 at 288.

14 Richard H. McAdams, "The Origin, Development, and Regulation of Norms" (1997) 96 Mich. L. Rev. 338 at 340 . Although MeAdams goes on to reject this definitien, he describes it as typical of the norms literature in general.

3 Posner, Law, supra note 32 at 18-19; Mc dams, "Signaling," supra note 32 at 627 . Discount rates attempt to calculate the cost of foresecable future costs in present value terms. See Robert H. lirank, "Why is Cost-Benefit Analysis So Controversial'?" in Adler \& Posner, supra note 13, 77 at 79.

Rostain, strpra note 15 at 990-91. In the Prisoner's Dilemma game, two prisoners would minimize their respective sentences if they both co-operate by refusing to confess. However, if one prisoner confesses/defects while the other prisoner co-operates, the prisoner who refuses to confess would suffer the worst pessible sentence. Therefore, neither prisoner will rationally confess nor co-operate and they will both get a moderate sentence even though this outcome is sub-optimal. See Posner, Law, ibid, at 1215.

37 McAdams, "Signaling," supra note 32 at 635.

38 Posner, Law, supra note 32 at 133-47.

39 McAdams, "Signaling," supra note 32 at 652 (noting that "it is the supreme contradiction of signaling theory that the racist ideology labeled Blacks as being short-sighted and impulsive - having a high discount rate - the very fact Posner identilies as giving everyone a reason to avoid them" [ footnotes omitted]); Hamish Stewart, "Economic Analysis ol"Law: Which Way Ahead?," Book Review of Law's Order: What Economics Has to Do with Law and Why It Matsers by David D. Friedman. Law and Market Economu: Reinterpreting the Values of Law and Economics by Robin Paul Malloy, Lani and Social Norms by liric A. Posner, and Behavioral Law amd Ecomomics by Cass R. Sunstein, ed., (2003) 53 U.T.L.J. 425 at 436 (observing "[b]|ut no one can doubt that racist beliefs are real: they are not simple rationalizations for costly behaviour but sincerely held beliefs that individuals are willing to incur significant costs to defend, even if changes in other social norms have made the signaling value of racist behaviour zero. or even negative, because under new norms it indicates that the individual is an uncooperative bad type" (at 436)). 
apparent weaknesses, law and social norms theory provides real possibilities for examining how disability discrimination legislation might impact on attitudes toward people with disabilities.

One distinct strand within the law and social norms tradition, known as expressive law, relates to the analysis of the relationship between law and the social and symbolic meaning of particular behaviours. ${ }^{40}$ Hence, there has been a greater acknowledgment that preferences do not simply result in. for example, particular pieces of legislation through a one-way exogenous effect of preferences on policy-making. Rather, the enactment of legislation or other changes in society may endogenously alter preferences by affecting either a person's beliefs, or his or her evaluation of the consequences of acting on the belief, which in turn greatly complicate the standard neo-classical model. ${ }^{41}$

A common example is the enactment of prohibitions on smoking that may cause smokers to quit smoking because of the increased awareness of the effects of smoking, fear of violating the law, or the increased pressure from other members of society to obey the new law. 12 This also highlights the crucial distinction between public awareness of a particular issuc and the enactment of legislation. "It may well be that public awareness of disability rights that accompany the passage of legislation on disability discrimination may be as effective in altering the preferences of individuals, and a social norm of discrimination and marginalization of people with disabilities, as the enactment of the legislation itself. On the other hand, it may be that no change in preference whatsoever occurs, but awareness that there is democratically enacted law is sufficient to create a norm that many individuals will follow regardless of their individual beliefs. ${ }^{44}$ Expressive law consequently sheds light on the relationship between law and social norms in an innovative and insightful way.

See e.g. Richard H. McAdams, "An Attitudinal Theory of Expressive Law" (2000) 79 Or. L. Rev. 339 at 340 (arguing that (1) there is a relationship between action and its perceived acceptability in the communily, (2) individuals have imperfect information about what is acceptable, and (3) denocratically enaced measures reflect the views of the community and may inlluence behaviour by signalling what is acceptable action); Richard H. McAdams, "A Focal Point Theory of Expressive Law" (2000) $86 \mathrm{Va}$. L. Rev. I 649 (arguing law provides a focal point around which individuals may coordinate their hehaviour); Cass R. Sunslein, "On the Expressive liunction of L.aw" (1996) 144 U. Pa. L. Rev. 2021 at 2024-25 [Sunstein. "Expressive Function of Law"] (analyring the design of legal interventions to aller social norms): Robert Cooter, "Expressive Law and Economics" (1998) 27 J. Legal Stud. 585 (developing the concept of "Pareto self-improvements" as basis for theory of preference changes); Alex Geisinger, "A Belief Change Theory of Expressive Law" (2002) 88 lowa L. Rev. 35 (arguing that law" affects norms by changing beliefs about the outcome of a given activity). For ease of exposilion, I rely' primarily on Geisinger's "belief change" theory.

S1 Scott A. Moss. "Women Cheosing Diverse Workplaces: A Rational Preference with Disturbing Implications for Both Occupational Segregation and Economic Analysis of Law" (2004) 27 Han: Womin's L.J. I at 79-80: Geisinger, ibid. al 63.

4: Stein, "Under the Fimpirical Radar." sapra note 10 at 1173-74. Sec also Jolls. Sunstein \& Thaler, "A Behavioral Approach," supra note 9 at 1496-97: Sunstein, "Expressive Function of Law," supra note 40 at 2034.

\$ Geisinger, supra note 40 at 67.

4 Hid. at 69; Korobkin \& Ulen, supra note 10 at $1131-33$ (noting that - $[$ b|y implementing nondiscriminatory hiring practices for government employees, for example, lawmakers might encourage a more general nondiscrimination norm" (at I I33)). 
Analyzing social norms also facilitates a more thorough understanding of the judicial backlash that many feel has occurred against the $A m e r i c a n s$ with Disabilities $A c t,{ }^{45}$ resulting in judicial rulings that have considerably narrowed the class of persons who qualify as having disabilities for the purposes of the $A D A$. This requires one to first distinguish between laws that are designed to enforce existing social norms, and laws that are designed to transform them. ${ }^{\text {th }}$ Given the long struggles for equality by people with disabilities and the significant changes that an employer must often make as accommodations for people with disabilities, one should regard the $A D A$ as a transformative law. The effect of a transformative law incvitably depends on how effectively established norms work to alter or de-radicalize the transformative intent of laws such as the $A D A$ through interpretations of legal rules that are more in keeping with the established norms. ${ }^{47}$ In the case of the $A D A$, this was particularly easy because the disability rights movement was relatively weak and the social model notions that drove it were poorly understood by much of the public despite enactment of the legislation. ${ }^{48}$ There was not a widespread popular consciousness in the general population about discrimination faced by people with disabilities that animated the passage of the $A D A$, unlike in the case of sex discrimination legislation passed to protect women or the canonical example of the civil rights movement for African-Americans. ${ }^{41}$ Traditional social norms affect the perception and interpretation of the legislation because many commentators wrongly interpret it as wholly related to social welfare rather than a piece of anti-discrimination legislation. ${ }^{50}$ These insights are entirely in keeping with mounting a case for the first principle which 1 maintain one can derive from the social model of disablement: greater worker control over day-to-day issues. Only such a systematic approach of worker empowerment has a real hope of remedying widespread discrimination where transformative legislation is derailed by judicial intransigence and nourished by public ignorance about the lives of people with disabilities. To the extent that the law and social norms tradition explains the undermining of the $A D A$ 's radical potential in this regard, it has real value.

Having acknowledged its strengths, I believe that the law and social norms tradition retains many of the same flaws of the behavioural law and economics school. While it may seem superficially more sophisticated and does hold some value as highlighting how activist

4. Americans with Disubilitie's Act, 42 U.S.C. $\$ 12101(1990)[A /) A]$.

to Linda I lamilton Kricger, "Afterword: Socio-Legal Backlash"(20(x)) 21 Berkeley J. Emp. \& Lab. L. 476 at 477. 519 [Krieger, "Alterword"]. See also Mary Johnson, "Belore ils Time: Public Perceplion of" Disability Rights, the Americans with Disabilitics Act. and the Future of Aceess and Accommodation" (2007) 23 Wash. U. J.L. \& Pol'y 121 at 122-23. I do not mean to imply that backlash is the sole explanatory variable for the judicial interpretation of the $A D A$. For a compelling argument that disability rights activists themsclves articulated a quasi-libertarian ideology that courts then used, see Samuel R. Bagenstos. "The Americans with Disabilities Act as Welfare Reform" (2003) 44 Wm. \& Mary L. Rev. 921 at 958-75.

4" Kricger. "Alterword," ibid. at 486. See also Karl L. Klare, ".ludicial Deradicalization of the Wagner Act and the (Origins of Modem Legal Consciousness, 1937-1941" (1978) 62 Minu. I. Rev. 265, for a classic account of the conservative interprelation of the Depression era Wagher Ac, the statule that eslablished collective bargaining rights lar Anerican workers and later served as the basis lor the Canadian labour relations regime.

th Kricger, "Atlerword," ihid, at 491.

ty Hid. al 489 .

(1) Ihid. at 516 . This is not to suggest that the $A D A$ does not have redistributive consequences. It most certainly does. Ilowerer, the failure to see the rights aspect is disturbing. 
social movements and legislative enactments may interact to shape preferences, the law and social norms school ultimately relies upon a flawed rational actor model centred narrowly on maximizing self-interest, and therefore presumes that the common good can be obtained by crafting social norms that facilitate this. ${ }^{\text {s1 }}$ Moreover, the general thrust of the law and social norms tradition is highly critical of legislative initiatives in favour of informal norms that bypass legislation, a bias that makes it of limited use to advocates of the social model of disablement. ${ }^{52}$ The principle of greater worker control over day-to-day production decisions in the workplace, as well as the second principle of the provision of disability supports across the lifespan, suggest a much more radical and comprehensive critique is necessary.

One needs to recognize that rationality itself is socially constituted and mediated. Rationality does not simply emerge out of a black box known as a social norm, but is shaped by ideas in society about what is fair and legitimate. ${ }^{53}$ Consequently, the profound implications of the social model of disablement for labour markets cannot be appreciated unless one has a conception of rationality that transcends mere self-interest and, instead, encompasses notions of solidarity and obligation to help those in need. ${ }^{54}$ Only with such insights can one be equipped with the relevant tools for evaluating Canadian and American labour markets for workers with disabilities.

\section{InSTITUTIONALISM}

Institutionalist economics was rooted in ideas propounded in the economically turbulent last decades of the nineteenth century and the first few decades of the twentieth century by noted economists such as Thorstein Veblen, Henry Carter Adams, Richard T. Ely, John R. Commons, Edwin Seligman, Robert Hale, Wesley C. Mitchell, and Clarence E. Ayres. ${ }^{55}$ Influenced by Wilhelm Roschler's German Historical School ${ }^{56}$ and by the politics of the Progressive Movement, ${ }^{57}$ institutionalism sought, by paying close attention to the workings of human institutions and collective action, to provide a more realistic explanation for behaviour and structural constraints in the actual world than may be accounted for by neoclassical economics and its emphasis on self-interested rational individuals. ${ }^{58}$ It also rejected

Mitchell, "Understanding," supra note 32 at 189.

Ibid. at 235.

Edelman, supra note 32 at 186-87.

See Mitchell, "Understanding," supranote 32 (noting "[s]elf-interest is a remarkably contingent concept, fluctuating with desires and their atlainability. And we know from history, as we know from our own lives, that desires change as we grow, as our experiences vary and are decpened, and as we encounter the new and unexpected" (at 226)).

Mercuro \& Medema, supra nole II at 103; James E. Herget \& Stephen Wallace, "The German Free Law Movement as the Source of American L.egal Realism" (1987) 73 Va. L. Rev. 399 at 404-406.

Mercuro \& Medema, ibid. at 101-108. Sec also Gregory S. Alexander, "Comparing the Two Legal Realisms - American and Scandinavian" (2002) 50 Am. J. Comp. L. I 3 I at I37-4I; I lerget \& Walluce, ibid. (noting the role of Savigny in the German Historical School).

Herbert Hovenkamp. “The First (ireat Law \& Economies Movement” (1990) 42 Stan. I. Rev. 993 at 1002 [Hovenkamp, "Firsı"]; Herbert Hovenkamp. "Knowledge About Welfare: Legal Realism and the Separation of Law and Economies" (2000) 84 Minn. L. Rev. 805 at 821 [Hovenkamp, "Knowledgc"]. Hovenkamp, "First," ibid. at 1014: Mercuro \& Medema, supro note 11 at 101-29: Danicl T. Ostas. "Postmodem Economic Analysis of Law: Extending the Pragmatic Visions of Richard A. Posner" (1998) 36 Am. Bus. L.J. 193 at 224-26; Herbert Hovenkamp, "Positivism in Law \& Economics" (1990) 78 Cal. L. Rev. 815 at 820-21: Monon J. Horwitz. The Transformation of American law 1870-1960: 
the idea that individual preferences are the only legitimate basis for making judgments about welfare and turned to non-cconomic disciplines for rich sources of information on comparative interpersonal utility and welfare. ${ }^{59}$ In many ways, it paralleled and overlapped with the development of the legal realist tradition in its focus on institutional context. ${ }^{60}$

The legitimacy of trade unions was also explored by institutionalism economists who recognized the enormous bargaining power of the employer and argued that this led to an inefficient labour contracting process. Therefore, total welfare could be increased if a portion of the surplus, which existed because most workers, by definition, created a profit for the employer, were given to the most impoverished workers whose marginal utility of income was higher. This consequently justified state intervention to relax anti-union laws. ${ }^{61}$ Commons, who published an anthology entitled Trade Unionism and Labor Problems in 1905, argued that unionization for labourers was analogous to the incorporation form of business for entrepreneurs. He asserted that it was unreasonable for employers to call on labourers to increase their productivity because employers do not saturate the market with goods that lower their prices. ${ }^{\text {h2 }}$

While Commons' analysis may seem unsophisticated today, it was an early attempt to go beyond neo-classical critiques of trade unions as a constraint on competition. Institutionalism, therefore, constituted a dissident school of economics that flourished for a period and enunciated a systematic collection of principles and beliefs. These included an emphasis on the institutional environment within which economic behaviour occurs; a recognition that there is an interactive relationship between the economic transactions within the institutional environment and the institutional environment itself; an acknowledgment of the relevance of Darwinian evolutionary processes in explaining the relationship between rational actors and institutions; a focus on conflict within economic relationships rather than consensus; an appreciation of the need for structuring institutions to channel the conflicts that would inevitably arise; and a commitment to interdisciplinary scholarship that adopts the best insights from psychology, sociology, anthropology, and law. ${ }^{63}$

The Crisis of legal Orihodoxy (New York: Oxford University Press, 1992) at 194-98: Alexander, supra nole 56 at $137-38$.

sq Hovenkamp, "Knowledge," supra note 57 at 846-47.

w Ibid. at 850. See also Allen R. Kump. "Between-The-Wars Social Thought: Karl Llewellyn, Legal Realism, and the Uniform Conmmercial Code in Context"(1995) 59 Alb. L. Rev. 325 (discussing impact of institutionalist economics on legal realism); Neil Duxbury, "Is There a Dissenting Tradition in Law" and Economics?", Book Review of law and Economics by Nicholas Mercuro, ed., (1991) 54 Mod. L. Rev. 300 at 303 (noting similurities between institutionalism and legal realism).

61 Hovenkamp, "First," stipro nole 57 at 1009-11.

62 Bbid. at 1011: George R. Boyer \& Robert S. Smith. "The Development of the Neoclassical Tradition in Labor Economics" (2001) 54 Industrial and Labour Relations Review 199 at 201.

a)

Mercuro \& Medema, supra note 11 at 107. An example of Darwinian evolutionary thinking ean be illustrated from the work of institutionalist economist Wesley Mitchell discussing coordination. He observed that "[c]obrdination within an enterprise is the result of careful planning by experts: coördination among independent enterprises cannot be said to be planned at all; rather it is the unplanned result of natural selection in a struggle for business survival" (see Wesley Clair Mitchell. Business: Cycles, vol. 3 (Berkeley: University of Califomia Press, 1913) at 38). 
At its earliest stages, institutionalism influenced the drafting of the American Uniform Commercial Code ${ }^{64}$ and produced masterpieces such as Hale's 1923 article, in the form of a book review on coercion and the role of the state in structuring economic affairs that shattered the assumptions of neo-classical economics that the "normal" equilibrium involved merely rational actors exchanging goods without any coercive interference from the state. ${ }^{65}$ The impact of institutionalism on the regulation of labour markets was profound. Eventually it would influence the enactment of a variety of union-friendly pieces of labour legislation in the U.S. including the Norris-LaGuardia Act, the Wagner Act, and the Occupational Safely and Health Act. ${ }^{\text {th }}$ Job security and seniority rights in the workplace were central concepts that institutionalists helped to encourage. ${ }^{67}$ Internal labour market theory can also be seen as having its roots in institutionalist theory. ${ }^{6.8}$

With respect to the two central implications of the social model of disablement for labour markets, I think that institutionalism has natural advantages in facilitating analysis of structural hierarchy in workplaces that are necessary to understand how to empower workers in the daily production process. Similarly, in crafting policies that provide disability supports throughout the lifespan of a disabled person regardless of income level or labour market attachment, institutionalist theory enables one to realistically assess the structural implications of different configurations of support systems in a comprehensive manner. An institutionalist analysis would greatly facilitate understanding of how various methods of providing income support to injured workers would affect the labour market participation of injured workers. It would facilitate a greater appreciation of how seemingly benign regulations relating to workers' compensation in fact structure and delineate what is often an explosive and complex relationship between the state, injured workers and their families, their unions, and the employer. It is far more useful than the individualist orientation of the behavioural law and economics school. The main limitation of institutionalism lies in the fact that its theoretical development dates back to the early twentieth century and it has consequently been marginalized by the subsequent rise of neo-institutionalism.

\section{NEO-INSTITUTIONALISM}

Neo-institutionalism is a post-Chicago School of Law and Economics that also examines the role of institutions, including the legal framework such as statutes, the common law, and more informal modes of regulation, for their effects on the evolution of the economy through their constraints on opportunity sets. This modern school relies on the scholarship of thinkers such as Armen Alchian, Steven Cheung. Ronald Coase, Douglass North, and Oliver

As See Kamp, supres note 60.

os Robert Lec llale. "Coencion and Distribution in a Supposedly Non-Cocrcive Slatc," Book Review of Principles of National Economy by Thomas Nixon Carver, (192.3) 38 Political Science Quarterly 470.

of Norris-LaGuardia Act, 29 U.S.C. \$\$101-115 (1932); Wagner Act, 29 U.S.C. \$\$151-66 (1935): Occupational Sufery and Health Act, 29 U.S.C. $\$$ S 651.78 (1970).

6. Sanford M. Jacoby,"Fconomic Idcas and the Labor Markct: Origins of the Anglo-American Model and Prospects for Global Diffusion" (2003) 25 Comp. Lab. L. \& P'ol'y J. 43 at 44-45.

ax Kenneth G. Dau-Schmidt, "A Bargaining Analysis of American Labor Law and the Search for Bargaining Equity and Industrial Peace" (1992) 91 Mich. L. Rev. 419 at $431-32$; Seth D. Ilarris, "ReThinking the Economics of Discrimination: U.S. Ainva!s 1: Barmell, the ADA and the Application of Intemal Labor Market Theory" (2003) 89 lowa L. Rev. 123 at 125-26 [Harris. "Re-Thinking"]. 
Williamson ${ }^{69}$ Some major aspects of neo-institutionalism are an expansive understanding of the limitations that impact rationality, including incorporation of many of the insights of behavioural law and economics, a greater emphasis on the evaluation of economic processes rather than simply interpreting equilibrium analyses as in neo-classical theory, and an

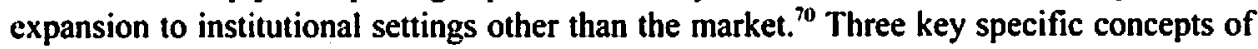
neo-institutionalism are property rights, contracting, and transaction costs. Property rights are crucial because they affect the distribution of wealth in a given economic system and they allocate resources through ownership, consequently affecting incentives that influence economic behaviour." Neo-institutionalist law and economics is therefore helpful in understanding how specific institutions alter property rights by, for instance, reducing the incentive of actors to invest in common property regimes even though the creation of institutions that specify property rights may be too expensive to arise in all circumstances. ${ }^{\text {? }}$ Zoning laws are an illustration of the assignment and virtual creation of property rights that may have significant implications for people with disabilities. ${ }^{73} \mathrm{~A}$ growing issue is what has become known as "visitability" or ordinances that require all new private housing to have minimal features that allow for wheelchair access, including non-residents, to visit all homes. ${ }^{74}$ Property rights and their alteration through the legal process play a critical role that neo-institutionalist analyses can help to interpret.

Similarly, the contracting process, as a fundamentally important mechanism for transferring property rights between parties, is seen as shedding light on the complex relationships between numerous rational actors that collectively form institutions such as firms. ${ }^{75}$ Whereas neo-classical law and economics envisions contracts that were fully defined, instantly in effect, and perfectly enforced by the judiciary, institutional theorists recognize that contracts are complex instruments that are often incomplete, do not necessarily come into effect for some time, and are not always fully enforced by the courts that contracting parties in any case often ignore through informal practices. ${ }^{76}$ In many respects, this analysis of the contracting process is similar to Duncan Kennedy's critical legal studies

Mercuro \& Medema, supra note II at 130-56; Edwin L. Rubin. "The New Legal Process, the Synthesis of Discourse, and the Microanalysis of Institutions" (1996) l09 Harv. L. Rev. 1393 at 1413-16; Ron Harris, "The Encounters ol Economic Hislory and Legal History" (2003) 21 Legal Hist. Rev. 297: Douglass C. North, Institutions, Institutional Change and Economic Performance (New York: Cambridge University Press, 1990) at 3-10; Oliver E. Williamson. The Mechanisms of Governance (New York: Oxford University Press, 1996).

Sec Christian Knudsen, "Modelling Rationality, Institutions and "'rocesses in Economic Theory" in Uskali Maki, Bo Gustafsson \& Christian Knudsen, eds., Rationality. Institutions and Economic Methodology' (New York: Routledge, 1993) 265 at 267. Knudsen provides this summary of the literature as a starting point to critique it. Mercuro \& Medema, supra note 11 at 131-33.

Ibid. at 133-34.

See Arlene S. Kanter, "A Home of One's Own: The liair Housing Amendments Act of 1988 and Housing Discrimination Against People with Mental Disabilitics" (1994) 43 Am. U. L. Rev. 925 at 928. See e.g. Eirin M. Davis, "A New York Perspective Regarding Aceess and Usability for the Disabled and Elderly in Private Residential Dwellings: What Can Be Done on a Local Level to Provide Basic Access and Usability in Private Dwellings Utilizing Cost Effective and Efficient Methods," Comment, (2002) 12 Alb. L.J. Sci. \& Tech. 917.

" Mercuro \& Medema, supra nute 11 at 142 (noting that "[t]he vast majority of contracting in modern capitalist economies is effectuated with firms as buyers and/or sellers, and often within the firm itself"). lbid. at $140-42$. 
scholarship on contract law doctrine. ${ }^{7}$ Such insights assist in formulating theories to explain the construction of contracts that provide accurate and calibrated incentives to managers that might otherwise opportunistically fire senior employees who are close to retirement and to workers that might otherwise have an incentive to shirk on the job since the incentives of the firm and the incentives of managers and workers diverge. ${ }^{78}$ In a fast-changing economy where more non-traditional employment structures are emerging, the neo-institutionalist literature on contracting may prove to be valuable because incentive structures matter a great deal.

A third building block of neo-institutionalist law and economics is transaction costs. They play a significant role in neo-institutionalist economics because they are not arbitrarily assumed away to be zero as in many neo-classical models, and their effects in potentially causing market failures if they rise to excessive levels are acknowledged. ${ }^{79}$ Building on the work of Coase, they include: the cost of information about the good that one is purchasing or the employee that one is hiring, the cost of the commitment of assets toward a contract that cannot easily be assigned elsewhere should the contract fail, the cost of precautions against opportunistic conduct on the part of the other party, and the cost of enforcement of the contract in the event that the another party breaches it. "In fact, transaction cost economics (TCE) constitutes a sub-school of its own right within neo-institutionalism focused on analyzing governance structures in a world of bounded rationality, incomplete information, and parties who may be motivated to secure specific assets with the aim of minimizing transaction costs where possible. ${ }^{81}$ Rules and their interpretation by courts and other bodies, which are highly malleable, can dramatically affect transaction costs and, therefore, the structure of agreements in particular employment markets.

A salient application of TCE is the evaluation of the importance of advocacy organizations in influencing public policy. In both Canada and the U.S., disability rights organizations have been advocates of legislation that empowers people with disabilities in the workplace. TCE allows one to determine the extent to which disability rights organizations have been able to increase social intelligence by informing decision-makers, such as elected politicians at all levels of government, about the issues facing workers with disabilities. ${ }^{83}$ Another more common example is corporations that apply TCE to factor in the impact that legislation such as the $A D A$ or human rights codes in Canada will have on the cost of accommodating their work forces as diflerent types of cases are litigated over time. ${ }^{k 4}$

Sec c.g. Duncan Kennedy. "Distrihutive and Patemalist Motives in Contract and Tort Law, with Special Reference to Compulsory Terms and Unequal Bargaining Power" (1982) 41 Md. L. Rev. 563 at 565. Mercuro \& Medema, supra note 11 at 143: Harris, "Re-Thinking." supra note 68 at 125-26, 138. See Michacl Ashley Stein. "The Law and Economics of Disability Accommodations" (20103) 53 Duke L.J. 79 at 157-5\%.

Rubin, sipro note 69 at 1413.

Mercuro \& Medema, supra note 11 :11 147.

Stein, supra note 79 at 159, n. 463.

Petcr H. Schuck, "Against (And For) Madison: An Essay in Praisc of' Factions" (1997) 15 Yale L. \& Pol'y Rev. 553 at 585.86 (noting "|s|pecial interest groups proside an important index of voters" willingness 10 "pay" for their policy goals" (at 585$)$ ).

See e.g. Steven F. Stuhlbarg. "Reasenable Accommodaltion Under the Americans with Disabilities Act: How Much Must One Do Before llardship Tums Undue'"' (1991) 59 U. Cin. L. Rev. 1311 at 1322-25. In the Canadian context, this can be seen by the description of an employer's accommodation policies provided and analy\%ed by LelBel J. in the reeent Supreme Court of Canada wrongful dismissal decision. 
Taken as a whole, I would argue that neo-institutionalist analysis serves well the two major principles I identified as evolving from the social model of disablement. I believe that neo-institutionalist frameworks are particularly suited to evaluating systems that may enable the empowering of workers. With respect to the establishment of disability supports across the lifespan, neo-institutionalist frameworks are also appropriatcly suited to analyze how different economic arrangements impinge upon the possibilities of realizing such supports in a dynamic environment with multiple variables that have interlocking and unpredictable effects. However, law and economics scholarship that investigates particular identitics is also insightful. I now turn to bodies of scholarship that consider the interplay between identities such as gender and race, on the one hand, and law and economics, on the other.

\section{E. Feminist Theory and LaW AND Economics}

Feminist theorists have also questioned many of the assumptions in neo-classical law and economics including those relevant for understanding labour market institutions and especially marginalized groups such as people with disabilities. ${ }^{85}$ By privileging the paid labour market, neo-classical accounts of women's lives often ignore the vital economic contribution that women have made through essential work in the household. ${ }^{86}$ Feminists have also pointed out that human capital models articulated by prominent economists such as Nobel Laureate Gary Becker wrongly suggest that the gender wage gap may be explained by the hypothesis that women have a comparative advantage in housework and that women therefore seek light low-wage employment in order to have sufficient energy and flexibility to perform both paid employment and tasks in the home. In fact, many feminist theorists have demonstrated decisively that while it is true that women disproportionately perform household labour, it is occupational segregation of women into low-paying jobs that explains most of the wage disparities, especially when detailed analyses of job categories within particular accommodations are conducted and tabulated. ${ }^{37}$ Moreover, the Becker human

Honda Canada v. Keays, 2008 SCC 39, 166 A.C.W.S. (3d) 685 at para. 99. Although LeBel J., writing in dissent, was critical of the employer's specilic methodology, the overall process used by IJonda is likely typical of many companics.

See (iillian K. Hadfield. "Flirting with Science: Richard Posner on the Bioeconomics of Sexual Man," Book Review of Sex and Keason by Richard A. Posner. (1992) 106 Harv. L. Rev. 479 [Hadficld. "Ilirting with Science"|) Gillian K. Hadfield, "Rational Women: A Test for Sex-Based Harassment" (1995) 83 Cal. L. Rev. I 151 |Hadficld, "Rational Women"); Gillian K. Iladfield, "Households at Work: Beyond Labor Market Policies to Remedy the Gender (iap" (1993) 82 Geo. L.J. 89 [Hadficld, "Jlouseholds at Work"|; Vicki Schuliz, "Life"s Work" (2000) 100 Colum. L. Rev. 1881; Martha T. MeCluskey, "Subsidized Lives and the Ideology of Lfficiency" (2000) 8 Am. U. J. Gender Soc. Pol'y \& L. 115; Darren Bush, "Caught Between Scylla and Charybdis: Law \& Economics as a Useful Tool for Jeminist Legal Theorists" (1999) 7 Am. U. J. Gender Soc. Pol 'y \& L. 395. For a response hy Posner 10. inter alia, Hadfield's review and her rebutal, see Richard A. Posner, "The Radical Feminist Critique of Sex and Reason" (1993) 25 Conn. L. Res. SIS; Gillian K. Hadlield. "Not the "Radical' Feminist Critique of Sex and Reason" ( 1993 ) 25 Conn. L. Rev. 533.

wh Hadlicld, "Flirting with Science," ihid. at 486-87.

87 Sclultz, stpra nole 85 ut $1893-98$ (noting sludies indicating up to 96 percent of gender wage disparitics may be explained by oceupational segregation depending on the methodology of the study at 1894, 11. 40). See also Michael Selmi. "Care, Work, and the Road to Equality: A Commentary on fintman and Williams" (2001) 76 Chicago-Kent L. Kev. 1557 at 1561-62 (easting doubl on the accuracy ol human capital explanations of gender wage disparities). But see generally Hadfield. "Houscholds at Work." supra note 85 (arguing that labour market policies alone cannot explain the gender gap in wages). Even if Hadfeld is correct on this point in emphasizing the importance of the houschold, this hardly means that women have a comparative advantage in doing housework as her own scholarship illustrates. See 
capital model postulating that women have a "taste for housework" fails to explain why it is housework, predominantly performed by women, that is unpaid labour and work outside the home that is paid. ${ }^{88}$ Feminist scholarship provides a basis for understanding how many rehabilitation professionals have historically deemed sheltered workshops to be an appropriate choice for people with disabilities, despite the stigma and extremely poor wages, often below the minimum wage, paid by such institutions. ${ }^{84}$

Child care arrangements and sexual harassment are two specific and important dimensions of women's participation in the labour market that have not been adequately analyzed by neo-classical commentators. Feminist critics of neo-classical law and economics have shown how debate on child care policy, particularly in the U.S., has been mired in this troubling efficiency/redistribution dichotomy. Government funding or subsidies for child care are regarded by policy makers as inefficiently redistributing wealth to mothers that could be more productively spent elsewhere in the economy at a cost of higher unemployment and higher prices for consumers. ${ }^{90}$ Yet this analysis is based on the assumption and political evaluation that certain forms of subsidies, such as "corporate welfare bum" subsidies provided to corporations by state and local governments in the U.S. that amounted to some US $\$ 50$ billion annually during the 1990 s, are entirely legitimatc."

Similarly, extensive subsidies for sports franchises are perceived as improving a community's morale or spirit. ${ }^{92}$ On the other hand, subsidies for child care are often perceived as a burdensome redistribution of wealth to mothers, particularly the much demonized single mothers, who may undermine the existence of the traditional nuclear family rather than eliminating a bias in favour of the patriarchal family that benefits heterosexual men who neglect their family responsibilities. ${ }^{33}$ Yet there is no principled economic reason why well-designed child care programs could not be rational and efficient, while greatly enhancing the quality of life for women in general and especially single mothers. ${ }^{-4}$ The obvious parallel for disability policy is the establishment of well-funded attendant care programs that enable people with disabilities to live independently by providing assistance with activities of daily living such as bathing, dressing, and

Hadlicld, "Houscholds at Work." supros nole 85 at $97-98$.

Schultz, ibid. at 1897-98.

David L. Braddock \& Susan L. Parish. “An Institutional History of Disability" in Gary L. Albrecht, Katherine D. Seelman \& Michatel Bury, eds.. Mamdbook of Discabilify. Sundies (Thousand Oaks, Cal.: Sagc, 2001) 11 at 42-45; The Rocher Institute. Disabilin: Commmity and Society: Exploring the Links (North York, Ont.: The Roeher Institute, 1996) at 86-88. See also Calherine J. Kudlick, "The Outlook of The Problem and the Problem with the Oulook: "Two Advocacy Journals Reinvent Blind People in Tum-of-the-Century America" in Paul K. Longmore \& Lauri Unansky, eds., The New Disability History: American Perspectives (New York: New York University Press, 2001) 187 at 196-97.

McCluskey, stupra nole 85 at $125-27$.

Bhid. at 140-41. This massive ligure dees not even include considerable lederal subsidies provided to "corporate welfare bums" in the U.S.

Ihid. at 143 (noling massive LSDS374 million subsidy by the Stale of Connecticut to ficilitate the relocation of a football team to Hartford and $\$ 60)$ million for the Bullalo Bills).

Bid. at 147.

Schulv. supra note 85 at 1915 (discussing role of quality child care services in France in alleviating poverty among single mothers). 
housework. ${ }^{95}$ An appreciation of feminist law and economics theory paves the way for a critique that would not regard such programs as excessive subsidies for people with disabilities, but as an essential basis for their participation. ${ }^{96}$

Sexual harassment has also been conceptualized by feminist law and economics theorists in explicitly economic terms as a way of reframing an issue that has previously often been mistakenly regarded by many as a matter of hyper-sensitive female employees intolerant of workplace banter. Instead of closely analyzing the psychology of misunderstandings that interrogates the conduct of the complainant, using an economic model plausibly simplifies the highly subjective and controversial jurisprudential debates on what conduct is sufficiently harmful to constitute sexual harassment in specific cases, to instead focus on its detrimental economic impact on female employees. ${ }^{97}$ This impact can take many forms including an exodus of female workers from male-dominated occupational categories, a decision to avoid certain categories of employment in anticipation of potential harassment, an expansion of time and energy devoled to dealing with harassers instead of work-related projects, an inability to loster the necessary relationships with mentors because of their harassment, and a loss of wages because of poor evaluations stemming from harassment. ${ }^{9 k}$

The basis for this new approach is defining conduct as illegal sexual harassment when sexbased conduct imposes a cost sufficiently high to induce a rational woman to change her workplace behaviour to her detriment, such as, for instance, not going on an overnight business trip where she might be harassed, under conditions in which she could do so costlessly. ${ }^{94}$ This interface between feminist legal theory and law and economics demonstrates how feminist law and economics can make a real contribution to a vexing policy problem as well as suggest possibilities that can enrich an understanding of disability discrimination. Indeed, tentative scholarship in the U.S. has now emerged on the notion of disability-based harassment under the $A D A$, although it is still at an early stage of

Sec generally Andrew L. Batavia, "A Right to Personal Assistance Services: "Most Integrated Setting Appropriale" Requirements and the Independent Living Model of Long-Term Carc" (2001) 27 Am. J. L. \& Med. 17. For a compelling Canadian account, sce Kari Krogh \& Jon Johnson, "A Life without Living: Challenging Medical and liconomic Reductionism in Home Suppor Policy for People with Disabilities" in Pothier \& Devlin, supra note 5 at $151-76$.

Unfortunately, courts have not always agreed with the social model framework of disablement. In Fernandes v. Memitoba (Direcror of Social Services H'inmipeg Central) (1992), 93 D.L.R. (4h) 402, leave to appeal to S.C.C. refused, 23169 (15 April 1993), the Manitoba Court of Appeal upheld a decision of the Social Services Advisory Committee dismissing the appellant's appeal from a decision of the Director of Income Security ruling that the appellant's request for funding to hire an altendant so that he could live outside a hospital setting ought to be denied as the authorities in question were not empowered to consider the appellant's allegations that his rights under ss. 7 and 15 of the Camadian Charter of Rights and Freedoms, Part I of the Constinution Act, 1982, being Schedule B to the Canda Act 1982 (U.K.) 1982. c. I1, were violated. Sce also Lynn A. Iding, "In a Poor State: The Long Road to Human Rights Protection on the Basis of Social Condition" (2003) 41 Alta. L. Rev. 513 at 521-22. But sec British Columbia v: Hulchimsum. 2005 BCSC 1421, 261 D.L.R. (4h) 171 (upholding the human rights tribunal linding that a provincial program funding attendant services for people with disabilities discriminated against the father of the adult disabled daughter on the basis of disability and family status by refusing to fund family members as paid attendants). Hadfield, "Rational Women," sum'a note 85 at 1152-56.

lbid. at $1169-75$.

lbid. at 1180 . 
development. ${ }^{100}$ While no Canadian secondary literature yet addresses disability harassment per se, a number of human rights boards of inquiry and boards of arbitration have ruled that disability harassment violates the various federal and provincial human rights codes even if such harassment is not always found to have occurred on the facts. ${ }^{101}$

Clearly, feminist interpretations of law and economics have much to contribute. In terms of furthering an understanding of the two implications of labour markets as seen through the prism of the social model, I think it is evident that feminist law and economics would be ideally suited to this task because its insights into how traditional values marginalize women's labour and penalize women for failing to conform to male norms can be directly applied to the case of workers with disabilities. Feminist theories of law and economics that challenge patriarchy and reveal male bias in everyday work practices facilitate critiques of power that are essential for achieving the goal of greater worker control over day-to-day issues in the workplace. The same principles can be used to denaturalize typically unnoticed barriers for people with disabilities in the workplace. Second, it would be directly applicable in defending the need for a comprehensive system of disability supports that stretch across the lifespan. Just as child care was transformed from a personal problem that individual women faced to a political issue, the same can be done to make the provision of disability supports a profoundly political question.

\section{F. Critical Race Theory and Law and Economics}

Critical race theorists and those who analyze the concerns of those workers who lie at the intersection of multiple grounds of discrimination have likewise made important contributions on the topic of law and economics. ${ }^{112}$ Critical race theory (CRT) emerged as

See Mark C. Weber, Disability Harcassmen (New York: New York University Press, 2007) 43-60; Mark C. Weber, "Exile and the Kingdom: Integration. Uarassment, and the Amtricans with Disabilities $A c t$ " (2004)63 Md. L. Rev. 162; Mark C. Weber, "Workplace Jlarassment Claims under the Americans with Disabilities Act: A New Interpretation" (2003) I4 Stan. L. \& Pol'y Rev, 24l at 250-58; Lisa Fichhom. "Hostile Environment Actions, Title VIt, and the ADA: The Limits of the Copy-and-Paste Function" (2002) 77 Wash. L.. Rev. 575 (discussing limitations of 'Title VII jurisprudence for coherent analysis of $A D A$ disability harassment); Leah C. Mycrs, "Disability Harassment: Itow liar Should the AD $A$ Follow in the Footsteps of Title VII?" (2003) 17 B.Y.U.J. Pub. L. 265 (proposing use of a reasonable viclim standard in evaluating disability harassment cases); Holland $M$. Taltvonen, "Disability-Based Harassment: Standing and Standards for a "New' Cause of Aclion." Note. (2003) 4 Wm. \& Mary L. Rev. 1489 at 1517.18 (suggesting, inter alica, identification of disability in reasonable person standard for use in disability harassment cases could destroy solidarity of the disability rights movement): Christine Neagle. "An Analysis of the Applicability of Hostile Work Environment Liability to the ADA" (2001) 3 U. Pa. J. Lab. \& Employment L. 715 (defiending use of disability to modify reasonable person standard). C.H.R.R. D.354 (Nfid. S.C.T.D) (negative relerences and notations by medical school with respect 16 medical student with speech impairment constituted harassment on the basis ol disability); Cargill l.th. v. United Food and Commercial Workers Imernational Union. Local II/8 (2004). 76 C.L.A.S. 380) (Arbitrator Power) (verbal comments about worker's plysical disability crealed hostile environment). Richard Delgado, "Resdrigo's Roadmap: Is the Marketplace Theory for litadicating Discrimination a Blind Alley?", Book Review of Jmerica in Block and Whise: One Natson. Indivisible by Stephan Thernstrom \& Abigail Thernstrom, and Wha / Means of Be a Liberiarian: A Persomal Imerpretation by Charles Murray, (1998) 93 Nw. U.L. Rev. 215; Richard Delgado, "Rodrigo's Sixth Chronicle: Intersections, Fssenets, and the Dilemma of Social Reform" (1993) 68 N.Y.U.L. Rev. 639; Richard Delgado, "Rodrigo's Second Chronicle: The Economics and Politics of Race," Book Review of 
an analytical framework as a consequence of the impasse of the American civil rights movement to advance substantive economic equality for African-Americans once the formal Jim Crow racial barriers had been eliminated with the passage of key legislation outlawing racial segregation and voting rights. ${ }^{103}$ Despite these important reforms, many AfricanAmericans still experience substantial economic deprivation and, most notoriously, the promise of Brown v. Board of Education ${ }^{104}$ has largely failed to desegregate American public schools. ${ }^{105} \mathrm{CRT}$ was an attempt to grapple with the profound limitations of the liberal civil rights model centred on individual racism as well as increase the representation of voices of colour in the American legal academy at a time when the liberalism of the 1960s was dissipating and more conservative values were in ascendance in the U.S. ${ }^{106}$

It also sought an intellectual engagement with the critical legal studies (CLS) tradition that left CLS fundamentally transformed. CRT insisted on the importance of rights in particular contexts and the need to engage in a thorough interrogation of how race affects all aspects of social life. This was at a time when the cultural meaning of being black evolved in a more multifaceted way as African-Americans entered many professional jobs yet in many cases were still less likely to invest in human capital because of continued patterns of discrimination. ${ }^{107}$ In short, it marked a dramatic shift from a paradigm of discrimination to one of subordination. ${ }^{10 x}$

Forbidden Grounds: The Case Against Enployment Discrimination Laws by Richard A. Epstcin, (1993) 91 Mich. L. Rev. 1183: Richard Delgado, "Crossroads and Blind Alleys: A Critical Examination of Recent Writing About Race." Book Review of Crossroads, Directions, and a New' Critical Race Theon. by Franciseo Valdes, Jerome McCristal Culp \& Angela P. Ilarris, eds. and Ethical Ambition: Living a life of lleaming and Worth by Derrick Bell, (2003) 82 Tex. L. Rev. 121 [Delgado, "Crossroads"]: Kimberle Crenshaw et al. eds., Critical Race Theory: The Rey, Writings That Formed the Moveme'n (New York: New Press, 1995); Francisco Valdes, Jerome MeCristal Culp \& Angela P. Harris, eds., Crossroads, Directions, anda New Critical Race Theory (I'hiladclphia: Temple University Press, 2002) [Valdes, Culp \& Harris, Crossroads]; Devon W. Carbado \& Mitu Gulati, "The Law and Economics of Critical Race Theory," Book Review of Crossroads. Directions, and a New Critical Race Theory by Francisco Valdes, Jerome McCristal Culp \& Angela P. Harris, eds., (2003) 112 Yale L.J. 1757; Clark Freshman. "Prevention Perspectives on 'Different' Kinds of Discrimination: From Attacking Different 'Isms' to Promoting Acceptance in Critical Race Theory, Law and Economics, and Empirical Research," Book Review of Pervasive Prejudice? Unconventional Evidence of Race and Gender Discrimination" by lan Ayres, and Crossroads, Directions, and a New Critical Race Theory by Francisco Valdes, Jerome MeCristal Culp \& Angela P. Harris, eds.. (2003) 55 Stan. L. Rev. 2293; Jerome M. Culp. Jr., Angela P. Harris \& Francisco Valdes, "Subject Unrest" (2003) 55 Stan. L. Rev. 2435 [Culp Jr., Harris \& Valdes, "Subject"]: Anthony Bentelli."Markeling Ratism: The Imperialism of Rationality, Critical Race Theory, and Some Interdisciplinary Lessons for Neoclassical Economics and Antidiscrimination Law" (1997) 5 Va. J. Soc. Pol'y \& L. 97; Christian Sundquist, "Critical Praxis, Spirit Healing, and Community Activism: Preserving a Subversive Dialogue on Reparations" (2003) 58 N.Y.U. Ann. Surv. Am. L. 659. Delgado, "Crossroads," ihid. at 125-26.

347 U.S. 483 (1954).

Bertelli, supra note 102 at 101 . Sec also Richard Thompson Ford, "Brown's Ghost" (2004) 117 Ilarv. L. Rev. 1305.

Kimberlè Williams Crenshaw. "The First Decade: Critical Reflections, or 'A Foot in the Closing Door, ". in Valdes. Culp \& I larris, Crossroods, supra nole 102, 9 at 10.15 (discussing the 1981 controversy at Harvard Law School over lack of racial minorities on faculty and lack of eourses reflecting racial issues). Ibid. at 15-18 (discussing how the critical legal studies (CLS) tradition made the "race lurn" and the initial hostility to Critical Race Theory by some White CLS theorists); Kimberle Williams Crenshaw. "Race, Reform, and Retrenchment: Transformation and Legitimation in Antidiscrimination Law" (1988) 101 Harv. L. Rev. 1331 at 1383-84.

Culp Jr., Harris \& Valdes. "Subject," supra note 102 at 2448. 
As the need for intersectional analysis addressing overlapping areas of discrimination has become increasingly acknowledged to ensure that the experiences of all marginalized groups are included in legal scholarship, CRT has since spawned branches that address the concrete struggles of Latinos/Latinas, ${ }^{(10)}$ Asian Americans, ${ }^{110}$ and gays and lesbians of colour. "1" As disability status obviously cuts across all racial lines, a true understanding of the legal regulation of workers with disabilities requires one to appreciate how American and Canadian labour markets have been racialized. Workers of colour who are racialized and also have disabilities often face barricrs, including in some cases linguistic barriers, in accessing resources such as disability supports and assistive devices that they require because of poor training of vocational rehabilitation staff of the needs of racial minorities. ${ }^{112}$ There is also the problem that credentials of immigrants are often not recognized, forcing them to accept employment in precarious contract positions with few benefits and contributing to greater poverty among racial minorities with disabilities. ${ }^{113}$ Women with disabilities who are members of visible minorities face overlapping barriers on all three levels. Yet they are not simply overlapping. It is often the case that membership in multiple minority groups results in an augmentation and accentuation of discrimination and stigma that would not be experienced by members in any single group. ${ }^{114}$

One application of CRT that merits consideration is the notion of race as a performative identity. By this, CRT scholars mean that the way in which an African-American person is treated is not simply a matter of phenotype and racial animus, but how an individual presents his or her blackness in the workplace and how this presentation is received by the minority worker's colleagues."'s This allows one to develop the concept of racial palatability, a concept that is striking for its resemblance to Becker's taste for discrimination. ${ }^{16}$ Racial palatability refers to the extent to which a black person engages in constructing a performative identity that signals to the broader society that he or she is uncenventional and, therefore, the negative stereotypes associated with most such persons ought not to apply to him or her. ${ }^{17}$ Workplaces of all sizes participate in a market of racial palatability where people of colour construct personal identities that, to a greater or lesser degree, conform to

See e.g. Elizabeth M. Iglesias \& Francisco Valdes, "LatCrit at live: Institutionalizing a Postsubordination Future" (2001) 78 Denv. U.L. Rev. 1249.

See e.g. Robert S. Chang, "Toward an Asian Ameriean l.egal Scholarship: Crilieal Race Theory, PostStructuralism, and Narrative Space" (1993) 81 Cal, L. Rev. 1241; Elbert Lin, "Identifying Asian America" (2004) 33 Sw. U.L. Rev. 217.

See c.g. Victoria Ortiz \& Jennifer Elrod, "Construction Project: Color Me Queer + Color Me Family = Camilo's Story" in Valdes, Culp \& Harris, Crossrocuds, supra note 102, 258.

National Council on Disability, Meeting the Unique Netds of Mfinorifies with Disabilities: A Report to the President and the Congress (26 April 1993). online: National Council on Disability <http:/www.ncd.gov/newsroom/publications/1993/minority.htm>.

See c.g. Rober D. Willon. "Working at the Margins: Disabled People and the Growth of Precarious Employment" in Pothicr \& Devlin, supra note 5, 129 at 142.

See e.g. Anita Silvers, "Reprising Women's Disability: Ietminist Identily Stratcgy and Disability Rights" (1998) 13 Berkeley Women's 1..J. 81 at 89 (suggesting multiple minority identities have an additive effect that magnilies stigmil).

Carbado \& Gulati, stupra note 102 at 1771.

See supra nole 87 and accompanying text.

Carbado \& Gulati, stupru nole 102 at 1772. Sec also K. Anthony Appiah. "Race, Culture, Identity: Misunderstood Connections" in K. Anthony Appiah \& Amy Gutmann, Color Conscious: The Political Morality of Race (Princeton: Princeton University Press, 1996) 30 at 78-79 (discussing how gap between a person's ascribed identily and the racial identity that the person performs enables racial passing). 
the tastes of the dominant group. Anti-discrimination jurisprudence in this model plays a role in structuring the market for racial palatability. It sets the boundaries of acceptable conduct for a member of a racial minority so that the conduct does not bar claims of racial discrimination. ${ }^{118}$

Consider the following illustration of racial palatability. Two female lawyers of colour, Lisa and Tancka, are being considered for partnership at an American law firm. ${ }^{119} \mathrm{Lisa}$ is the daughter of acudemics and a graduate of Ivy League institutions for both her undergraduate and law school education. She is married to an investment banker and is very active in the firm's recruitment committee as well as in the social activities of the firm. She has a reputation of reliability in emergencies at the firm as well as for her professional attire. Taneka, on the other hand, is the daughter of immigrants from Trinidad and only moved to the U.S. at the age of 12 . She spent her weekends helping her parents in operating their small restaurant. She attended public universities for both her undergraduate and law school education and graduated at the top of her law school class. She was the only member of her graduating class to receive an offer from her elite law lirm. At the firm, she was proactive in promoting a greater commitment for affirmative action. She also wore her hair in braids, despite concerns from some senior female partners about how acceptable this might be, spoke with a slight Caribbean accent, and attended few firm social functions. ${ }^{120}$ Even though both women have the same racial identity, their racial palatability varies dramatically because Taneka is seen as more racialized than Lisa and she would find it more difficult to demonstrate that she experienced racial discrimination because of her failure to conform.

This illustration conveys how racial identity is so much more complex than mere phenotype. Whereas Lisa is racially palatable to the mainstream law firm culture and has undertaken numerous steps to signal to the firm that racial stereotypes ought not to apply to her so that her colleagues will see her identity as part of the favoured in-group of professional lawyers rather than the marginalized outsider female A frican-American, ${ }^{121}$ Taneka is a much more controversial lawyer because she signifies that she is a black woman in a way that some traditional law partners may find threatening or may conclude that their clients would find discomfiting. There is a strong parallel to the disability community.

Consider a female lawyer, Andrea, who uses a wheelchair. She acquired a spinal cord injury in a car accident while she was an associate at her elite Bay Street law firm. Having graduated from a leading law school and clerked for the Supreme Court, Andrea brings a unique set of life experiences and socialization skills in play when she is under consideration for induction to the partnership. Contrast that with another associate, Vanessa, who also uses a wheelchair. She was bom disabled and speaks with a very slight speech impairment. Since many Canadian law schools were, and remain, highly inaccessible, Vanessa graduated from a relatively low ranking law school even though she had the grades and LSAT score to attend

Ibid.

For a discussion of how strategies on the part of minorities to identily as part of the in-group may actually intensify discrimination against other minorities who cannot so easily identify with the majority group. see Freshman, supra note 102 at 2330 . Of course, ironically, this stratcgy may not even consistently work even for the racially palatable Lisas. 
the top law schools. Furthermore, just like Lisa in the original example, Vanessa is well-liked although some partners have reservations about how her speech impairment may be perceived by certain clients. There is no question that Andrea is more palatable in terms of her disability than Vanessa even though it is far from clear that Vanessa's accommodation costs would actually be greater. Constructing a market for disability palatability allows one to better grasp the distinctions that many employers may make when hiring employees with disabilities and to appreciate the differences that Vanessa might face in trying to make a disability discrimination claim compared to Andrea.

At the same time, both Vanessa and Andrea must navigate complex physical and social barriers that are influenced by their gender, race, sexual orientation, social or class position, age, and age of onset of their disabilities. Andrea is likely to experience what some scholars have described as "biographical disruption" because she has to reconstruct her new identity as a lawyer that now uses a wheelchair for mobility. ${ }^{122}$ While her privileged education and class background mitigate this to some degree, she is still likely to face considerable uncase as she deals with the world anew as a disabled person and learns to find ways to deal with physical barriers in the workplace, transportation barriers, and ignorant attitudes about the capabilities of people who use wheclchairs. Although a person with a visible disability can never fully pass as able-bodied, Andrea's performance as an accomplished disabled person partly affects how her employer and clients regard her. In contrast, Vanessa's performance is affected by the consequences of barriers and discrimination related to the fact that Vanessa has experienced discrimination in education and in social situations over the course of her entire life. However, Vanessa, unlike Andrea, is likely completely comfortable in articulating her identity as a disabled person from sheer experience. This dichotomy is illustrative of the complexities that can arise.

Another remarkable proposal rooted in both law and economics and CRT is Derrick Bell's highly controversial advocacy for the enactment of a Racial Preferences Licensing Act. Bell affirms that such legislation would be an appropriate policy response to the impasse of equality rights for truly empowering African-Americans in the U.S. and the reality of racism as, in Bell's view, a permanent feature of life in American society where civil rights kegislation has simply failed to achieve significant gains for many African-Americans. ${ }^{13}$ Under this proposal, employers and proprietors of public accommodations may purchase an expensive licence that authorizes and, in fact, requires them to discriminate against racial minorities as specifted under the licence. During each fiscal quarter, licence-holders are also required to pay a tax of 3 percent of the income derived from employing or serving only Caucasians. ${ }^{124}$ This tax revenue is then placed in what Bell describes as an "equality fund" that would subsidize businesses for A frican-Americans, offer interest-lire mortgage loans for African-American home buyers, and provide scholarships for African-American applicants to universities and colleges. The equality fund's management would include

S. Michelle Dreidger, Valorie A. Crokks \& David Bennelt, "Fngaging in the Disablement Process over Space and Time: Narratives of Persons with Multiple Selerosis in Otlawa. Canada" (20104) 48 Canadian Geographer 119 at 126.

1: Derrick Bell, Fuces at the Bomom of the Well: The Pormmence of Rocism (New York: BasicBooks, 1992) al 47-64 [Bell, Fices]; Derrick Bell, "loreword: The Final Civil Rights Aet" (1991) 79 Cal. L. Rev. 597. See also Bertelli, stupra note 102 at 101-104. 
representation from the major civil rights organizations. Although allegations of racial discrimination cannot be made against licence-holders, allegations of racial discrimination against others may proceed on a dramatically simplified basis, allowing statistical or circumstantial evidence to be sufficient grounds to find liability. A finding of liability would result in damages of USD $\$ 10,000$ per act of unlicensed discrimination. ${ }^{125}$

Similar in some respects to granting licences to companies to pollute, ${ }^{126}$ this heuristic device has the advantage of moving sharply away from any notion of intent and wrongdoing of individuals, as is already the case in Canadian anti-discrimination law, that CRT scholars feel has so limited the ability of civil rights legislation to truly grapple with systemic racism and the reality of racial nepotism that favours Caucasians. ${ }^{127}$ Moreover, the explicit authorization of racial discrimination would allow enforcement of a ban on discrimination among non-licensees to be pursued more effectively and regarded more seriously, perhaps as quasi-criminal law. ${ }^{128}$ At the same time, a policy of permitting anyone to obtain a licence and then discriminating them would gain support from libertarian scholars who are opposed to the intrusion of civil rights laws on the rights of individuals to associate with whom they choose. ${ }^{12 "}$ It has to be emphasized, however, that it represents an intellectual argument to move discussion forward, rather than a policy proposal that actually has any serious chance of enactment. The commitment of both the Canadian and American governments to the current regime on human rights is clear: such a dramatic shift, notwithstanding the merits of licensing discrimination, would simply be neither feasible nor desirable.

Scholars have offered key modifications to make the licensing system work more effectively, such as suggesting that there ought to be a limit on the number of licences available and that they ought to be transferable. These modifications would mean only the most discriminatory companies would be able to purchase a licence and that the model could flexibly adjust to changes in the levels of prejudice in society. ${ }^{130}$ As well, it has been suggested that one could construct a mathematical model that distinguishes between the racial discrimination that one attributes to prejudice, which would remain unchanged regardless of knowledge, and discrimination that one attributes to ignorance and which declines with increased knowledge. ${ }^{131}$

Although the Racial Preferences Licensing Act is certainly an innovative approach, Bell is also not alone in proposing some variant of this paradigm for addressing racial discrimination. David Strauss has argued that discriminatory tastes by consumers will eventually result in either wage discrimination against minority employees or a segregated market with equal wages, both of which are disturbing outcomes to those who support equality; an alternative to the case-by-case approach to civil rights enforcement is

lbid. at 48-49.

Ihid. at 57.

Ibid. at 56 .

lhid. at 61.

Bertelli, supro nole 102 at 144-45.

lbid. at 112-13.

Ibid. at 111 . 
necessary. ${ }^{132}$ This is especially true because productivity differences on the basis of race, which will generate statistical discrimination issues, likely reflect an endogenous lack of investment in human capital as a result of systemic racism. ${ }^{133}$ Strauss therefore proposed moving away from a focus on disparate treatment, with its costly and bureaucratic emphasis on intent and individualized cases, to creating numerical standards that require a certain proportion of employees to be minorities. Companies must meet the minimum quota or pay fines in lieu. ${ }^{134}$

What are the implications for workers with disabilities? These approaches could easily be applied to disability discrimination and its "strict liability" paradigm would be a bold step in overcoming the numerous hurdles that complainants face in proving discrimination within equality frameworks in Canada and the U.S. Presently, both countries struggle to appreciate that accommodation and equality are not mutually exclusive concepts. In the American context, a general definition of disability in a licence would overcome the complex barriers to defining what a particular disability is. The immediacy of the remedy would be attractive to Canadian disability rights activists who are frustrated with endless delays in obtaining justice at human rights tribunals that are increasingly pereeived as deeply flawed institutions. ${ }^{135}$ Most important is the epistemological impetus that such an approach would bring to changing the terms of the debate. This is more critical than regarding this approach as a draft statute to be adopted tout court.

CRT interpretations of law and economics provide important tools for appreciating the two insights that I have derived from the social model of disablement. First, the basis for providing disability supports as a foundation for ensuring equality for people with disabilities is rooted in an analogous critique to the insightful CRT analysis of the limitations of rights for achieving substantive equality for racial minorities. Indeed, it is inevitable that the process of achieving equality for people with disabilities will emphasize their disabled identity in order to justify the provision of accommodations. Second, the notion of race as a performative identity may be directly applied to analyzing discrimination against people with disabilities. Finally, proposals such as Bell's Racial Preferences Licensing $A c t$ highlight how there may be alternative approaches to addressing discrimination, including disability discrimination. It expands the range of possibilities and the breadth of our vision and for that alone deserves serious contemplation.

In light of these critiques from a wide array of perspectives discussed in this article, the neo-classical law and economics framework is best regarded as offering a limited but radically incomplete heuristic approach, rather than a comprehensive paradigm that satisfactorily addresses the relevant questions for workers with disabilities. ${ }^{136}$ However. some

11. David A. Strauss, "The Law and l:conomics of Racial Discrimination in Employment: The Case for Numerical Standards" (1991) 79 Geo. L.J. 1619 at 1639.

13. David Charny \& G. Milu Gulati, "Efficiency-Wages, Toumankents, and Discrimination: $\Lambda$ Theory of" Employment Discrimination Law for "High-I.evel" Jobs"(1968),33 I Jar. C.R.C.C.L.L. Rev. 57 at 64-66. Strauss, supro notc 132 at 1654-56.

11. See e.g. Brian Etherington, "Promises, Promises: Notes on Diversity and Access to Justice" (2000) 26 Queen's L.J. 43. Whether the current reforms to the Ontario Human Rights Commission recently enacted by the Ontario government lead to real change remains to be seen. 
critiques of neo-classical law and economics are more salient than others. In my view, behavioural law and economics and the law and social norms school have limited relevance in explicating my central thesis given the methodological individualism of the first two schools and the vagueness and relative theoretical underdevelopment of the latter. Institutionalist law and economics is of limited modern relevance. The most useful frameworks that will be the background conceptual tools for analysis are neo-institutionalist approaches, feminist law and economics, and CRT. Future scholars would be wise to focus on these schools.

\section{ConClusion}

People with disabilities need practical solutions to their longstanding problems with respect to labour market participation. It is a tragedy that large numbers of Canadians and Americans with disabilities remain outside the labour market but it is one that can be changed. Critical schools of law and economics can play a vital role in ameliorating the problem. In this article, I have analyzed the major critical schools of law and economics in light of the two key factors I have derived from the social model of disablement. I concluded that the most useful alternative schools for promoting the rights of workers with disabilities were neo-institutionalist law and economics, feminist law and economics, and CRT law and economics. Future scholars will lind much to explore in these paradigms in explicating the problems and barriers faced by Canadian and American workers with disabilities. 